Article

\title{
Clashing Tactics, Clashing Generations: The Politics of the School Strikes for Climate in Belgium
}

\author{
Anneleen Kenis ${ }^{1,2}$ \\ ${ }^{1}$ FWO-Research Foundation Flanders, Division of Geography and Tourism, KU Leuven, 3001 Leuven, Belgium; \\ E-Mail: anneleen.kenis@kuleuven.be \\ ${ }^{2}$ Centre for Sustainable Development, Ghent University, 9000 Ghent, Belgium
}

Submitted: 22 November 2020 | Accepted: 1 February 2021 | Published: 28 April 2021

\begin{abstract}
Much has been written about the challenges of tackling climate change in post-political times. However, times have changed significantly since the onset of the debate on post-politics in environmental scholarship. We have entered a politicised, even polarised world which, as this article argues, a number of voices within the climate movement paradoxically try to bring together again. This article scrutinises new climate movements in a changing world, focusing on the School Strikes for Climate in Belgium. It shows how the movement, through the establishment of an intergenerational conflict line and a strong politicisation of tactics, has succeeded in putting the topic at the heart of the public agenda for months on end. By claiming that we need mobilisation, not studying, the movement went straight against the hegemonic, technocratic understanding of climate politics at the time. However, by keeping its demands empty and establishing a homogenised fault line, the movement made itself vulnerable to forms of neutralisation and recuperation by forces which have an interest in restoring the post-political consensus around technocratic and market-oriented answers to climate change. This might also partly explain its gradual decline. Instead of recycling post-political discourses of the past, this article claims, the challenge is to seize the 'populist moment' and build a politicised movement around climate change. One way of doing that is by no longer projecting climate change into the future but reframing the 'now' as the moment of crisis which calls on us to build another future.
\end{abstract}

\section{Keywords}

Chantal Mouffe; climate change; climate law; depoliticisation; intergenerational justice; new climate activism; politicisation; post-politics; School Strikes for Climate; technocracy; Youth for Climate

Issue

This article is part of the issue "Is There a New Climate Politics? Emergency, Engagement and Justice" edited by Anna R. Davies (Trinity College Dublin, Ireland), Stephan Hügel (Trinity College Dublin, Ireland) and Vanesa Castán Broto (University of Sheffield, UK).

(C) 2021 by the author; licensee Cogitatio (Lisbon, Portugal). This article is licensed under a Creative Commons Attribution 4.0 International License (CC BY).

\section{Introduction}

It is Thursday 10 January 2019. It is cold on the streets. A few people gather on the Carrefour de l'Europe nearby Brussels Central station. The atmosphere is reserved and nervous, almost feverish, at the same time. Would other people show up? Or would they be the only ones who decided to actually skip school and take to the streets? Not much later, small groups of pupils start flowing in from all sides. Slowly but certainly, the square is thronged with people. The atmosphere relaxes.
Enthusiasm grows. People start giggling and shouting. Some start singing. Soon, the square is too small for the crowd that has gathered. The crowd starts moving towards Rue de la Loi. Excitement rules. An improvised and spontaneous demonstration takes to the streets. More than 3000 young people, primarily secondary school pupils, participate in this first Belgian climate strike. They all responded to a Facebook video call of two teenage girls, Anuna De Wever and Kyra Gantois, to skip school for the climate. Their call was, in turn, inspired by Greta Thunberg, the 15-year-old Swedish climate activist 
who had been striking for the climate since September 2018. With the initiative, Belgium was put on the map as one of the first countries in Europe where School Strikes for Climate took place. Belgium would also turn out to be one of the countries with the highest number of participants, certainly relative to the size of the country. On Thursday 17 January 2019, no fewer than 14,000 pupils take the streets. The week after, 35,000 strike for the climate. On Sunday 27 January, the School Strikes for Climate feed into an earlier planned demonstration, leading to the biggest climate march ever in the country, attracting more than 70,000 participants. After this milestone, Youth for Climate, the platform which has been established in the meantime and which calls for the School Strikes for Climate in Belgium, decides to opt for a number of local demonstrations. On Thursday 31 January, 30,000 climate strikers are counted in Leuven and Liège. The week after, School Strikes for Climate take place in several cities, among which Antwerp, Leuven, Kortrijk, Brussels, Hasselt, Beringen, Liège, Bergen, and Herve. In total, the new climate movement organises 20 strike days in Belgium. The last demonstration takes place on Thursday 17 May, two days before the federal and regional elections. With the exception of 15 March, when the first Global Climate Strike for Future takes place, the Belgian strikes never reach the number of 30,000 people again. Still, the numbers stay significant for a long time.

The emergence of new social movements or, more broadly, new forms of social upheaval, is always intriguing. Why is large-scale social protest triggered at a particular moment? How come some mobilisations barely attract a few dozen people and others easily gather thousands and more? What was so appealing about the School Strikes for Climate? How come climate change suddenly succeeded in inspiring so many young people? A whole range of academic fields have tried to understand social movements' characteristics from a variety of perspectives. At the same time, it appears impossible to fully capture the rise of new forms of social upheaval in theoretical frameworks. There always seems to be something that escapes us. In that sense, like climate change itself, climate mobilisations seem to be characterised by unpredictability, non-linearity, feedback loops, and threshold points.

Without pretending to give the final answer on the 'how' and 'why' of the School Strikes for Climate in Belgium, in what follows, I will look at them from the perspective of post-foundational political theory. More in particular, I will draw on the work of Chantal Mouffe (2002, 2006, 2018) and Erik Swyngedouw (2010, 2013a) and, to a more limited extent, Jacques Rancière (1998, 2001) and Slavoj Žižek (1994, 2000). Key to this body of work is the notion of 'the political,' which concerns the 'discourses' through which social phenomena are constructed and given meaning. Politicisation is considered a core ingredient for democratic politics, but 'the political' can also get lost. This happens when discourses portray themselves as being devoid of power, conflict, and decision; realities which constitute the essence of politics. Of key importance is that it is on the level of ideas or representations - in other words, 'discourses' that the (de)politicised nature of social movements has to be assessed (Howarth, 2000; Howarth, Norval, \& Stavrakakis, 2000). Therefore, my focus will be not so much on the movement's social composition, resources, or number of participants (for work that takes up this challenge see, for instance, de Moor, de Vydt, Uba, \& Wahlström, 2020; Martiskainen et al., 2020), but on how the movement understands, represents, or gives meaning to itself and builds itself on this basis.

To that aim, I will write about the movement as a unified actor, even though I am aware that no such thing as a fully unified movement ever exists. The focus will be on the way in which the movement is represented to the broader public by its spokespersons, and the way it is framed on websites, social media, and television, and in newspapers, and magazines. While I have interviewed a number of people who joined the demonstrations, this data will not be the focus of the current analysis, as these people did not actively participate in the movement's framing towards the broader world. I am aware that, consequently, this article will not fully do justice to the diversity of the movement, and that some people might not recognise themselves in the picture I draw. For the sake of arriving at a distinct political-theoretical analysis, and because of the factual observation that a small group of spokespersons had a tremendously important impact on how the movement was presented to the outside world, I will present a rather homogenised account focusing on these public voices, partly making abstraction from the plurality of viewpoints which were present within the movement's rank and file. In that context, it is also important to underline that my analysis should not be read merely as an argument about the movement, but also as an intervention in the movement. In other words, it should not be understood as a distant critique, but as a way of building the movement exactly through engaging in a critical debate. While I am fully aware of the limits of the current analysis, it is my contention that looking at new climate movements from the perspective of 'the political' can help make sense of their successes and failures, as well as of the challenges, discussions, and tensions they face.

In what follows, I will first sketch the changing political condition within which the Belgian School Strikes for Climate appeared. I will argue that we have moved from a post-political to an increasingly politicised, even polarising world, and that it is important to situate the movement within this context. Second, I will contend that the Belgian strikes have triggered a politicising dynamic through their tactics, which were based on the controversial claim that there is no point in attending school when faced with climate change. Third, I will zoom in on the movement's choice for an intergenerational conflict line, showing how this choice on the one hand pointed 
to a potential subject of change, but risked homogenising both the future and the present on the other. Fourth, I will argue that this evolution, in combination with the movement's choice to keep its demands empty, opened the door to the movement's neutralisation and recuperation, which may partly explain its subsequent decline. I end the article with some reflections on how to seize 'the populist moment' (Mouffe, 2018) instead of recycling the post-politics of the past.

\section{The End of the Post-Political}

A lot has been written about climate change and the post-political (e.g., Bond, Diprose, \& Thomas, 2019; MacGregor, 2014; Machin, 2013; Maeseele, 2015; Kenis \& Lievens, 2014, 2015; Swyngedouw, 2007, 2010, 2013a). This literature does not only deal with the difficulties of tackling climate change in a depoliticised world, but also with the way in which the predominant climate narrative-characterised by its claim that 'we are all in this together,' which often underpins presumedly neutral market-oriented and technocratic policies-has historically contributed to reinforcing post-political tendencies. Indeed, the central argument of this literature was not only that an overarching depoliticised atmosphere influenced the way climate change was hegemonically approached, but also that the focus on an externalised enemy $\left(\mathrm{CO}_{2}\right)$ and the lack of a privileged subject of change have played a significant role in strengthening what was considered a post-political condition (Swyngedouw, 2010, 2013).

Importantly, the initial theories on the post-political were developed in the late 1990s and the first decade of the 21st century (Mouffe, 2002, 2006; Rancière, 1998, 2001; Žižek, 2000). The understanding of society in terms of a post-political condition was rooted in a historical situation in which political parties tended towards the centre, the neoliberal political economy had gained a historical victory, and consensus-seeking was key (Mouffe, 2002, 2006). The theoretical background of this literature, which was labelled post-foundational political theory (Marchart, 2007), starts from a distinction between 'politics,' on the one hand, and 'the political' on the other. Whereas the first refers to institutions like the parliament or voting, the second refers to a logic of thinking and acting which acknowledges the inevitability of division and conflict. Stating that we lived in a post-political condition therefore did not mean that there would no longer be 'politics' in the commonsensical meaning of the term (think about the game of party politics, the parliament, or voting), but that the constitutive dimension of conflict and plurality was not recognised anymore. The first analyses of climate change and post-politics would follow not much later (Swyngedouw, 2007, 2010). Importantly, this was also the period when the international climate summits became strongly mediatised and public events (Boykoff \& Pearman, 2019), most notably COP15 in Copenhagen in 2009 and to a lesser extent COP21 in
Paris in 2015, which lent themselves well to analyses in post-political terms (Goeminne, 2010; Kenis \& Mathijs, 2014; Swyngedouw, 2013a). Climate change was hegemonically approached in a market-oriented and technocratic way, and presumably neutral win-win solutions were advocated through which environmental, social, and economic concerns could supposedly be smoothly reconciled, and around which all stakeholders would easily unite (Kenis \& Lievens, 2015; Swyngedouw, 2013a, 2015). Where dissident voices came to the fore, they were often swiftly ridiculed, marginalised, and even criminalised. In this context, a crucial question, both academically and in activist circles, was how to repoliticise climate change.

However, the global political constellation changed significantly since the first work on climate change and the post-political appeared. From the election of US president Donald Trump in 2016 to the coming to power of Brazilian president Jair Bolsonaro in 2019, from the success of extreme right-wing parties in Poland, France, and Belgium to the rise of the tea party movement and the alt-right: The world has seen a dynamic of politicisation, even polarisation, though admittedly not entirely the kind of repoliticisation many critics of the post-political condition had pleaded or hoped for. To understand the normative character of post-foundational political theory, it is important to see that diagnosing the Zeitgeist as post-political was never meant as a merely descriptive gesture (Kenis, 2019). It has always been a form of ideology critique, starting from an emancipatory and democratic perspective, and this is exactly what many critics of the post-political thesis (McCarthy, 2013; Urry, 2011) have failed to acknowledge. In other words, the 'postpolitical' critique had a fundamental 'political' intention. Its aim was to denounce the undemocratic character of post-political affairs, and to generate a space in which resistance and opposition could become legitimate options again (Mouffe, 2006, 2018; Rancière, 1998; Žižek, 2000). The theoretical strategy to do this was to make the lack of an ultimate foundation of the hegemonic order visible and thereby contestable.

Looking from that perspective at the international evolutions in the second half of the second decade of the 21st century, an interesting development has taken place. Hitherto hegemonic orders, such as globalisation, free trade, and neoliberalism, lost their invincible position, and even climate politics was pushed out of its comfortable post-political place within which we would all agree. The Gilets Jaunes made clear to the entire world that climate politics is a class struggle and in no way an uncontested domain. It is in this context that we witnessed, and should make sense of, the emergence of the biggest grassroots climate mobilisations ever seen.

\section{Politicisation of Tactics}

Why should we continue going to school when there is no future waiting for us? (Youth for Climate, 2018) 
"There is No Planet B," "Act Now," "Climate Justice Now": The movement's main slogans do not sound very inspiring at first sight. They are exactly the same slogans as those used during the COP15 demonstrations in Copenhagen in 2009, and during all climate demonstrations that followed from then onwards. But what is new, radical, and turns out to be incredibly mobilising is the idea that it is legitimate, even necessary, to skip school to demonstrate against climate change. "Our only way to exert pressure is by skipping school, just as a labourer who strikes in his company," explains one of the movement's spokespersons in a newspaper interview ("Zo'n 3.000 klimaatspijbelaars," 2019). While the youth climate strikers are not the first to skip school for a higher goal, their tactics seem to be even more appealing because they resonate with the point they want to make. Tactics and message converge in the idea that there is no point in attending school when confronted with climate change: In order to tackle climate change, we need political pressure, not studying or even more science. With this argument, the movement breaks with the hegemonic technocratic approach to climate change, which elevates their tactics' stakes. As one of the movement's spokespersons states during a speech at the very first Belgian School Climate Strike: "We spend all our youth on school benches. The message is that studying hard will bring us far, but I don't believe that any longer. What is far? If all proof resulting from scientific research is simply neglected?" (De Wolf \& Arnoudt, 2019). This argumentation is part of a broader, international narrative that "'going to school begins to be pointless' with the climate crisis looming" (Fisher, 2019). Or, as two young climate activists state in a well-shared op-ed: "Why do we skip school for the climate? Our future does not only depend on our studies, but also on the climate" (Verbeke \& Vanderstricht, 2019). They add that time pressure strongly influences their strategies: "We do not have the time to wait till we have the right to vote or can become politicians ourselves." It is also this argument that provokes most reactions in first instance. Soon, a vast debate takes off on whether it is legitimate to skip school to demonstrate against climate change. Several right-wing, liberal and conservative politicians claim that the climate problem will not be solved by civil disobedience: "We also and especially need knowledge and technology. Therefore, we have to study, develop new ideas," as a well-cited academic claims (Boudry, 2019). Addressing the climate strikers directly, he states: "You can contribute to that as well, with your smart brains. Do you understand now why some people think it is ironic that, of all things, you leave school to save the climate?" The youth climate strikers do not show many signs of being impressed: "They tell us that we have to study, and get to know the science, but then we see that politicians neglect all science about the climate completely" (De Wolf \& Arnoudt, 2019). Whereas mainstream actors resort to a conventional technocratic discourse which underscores the importance of education, science, inno- vation, and expertise, more progressive voices embrace the movement's politicising push, arguing that we know by now what the problem is. Whereas the first stress that pupils have to obey public order, the latter argue that civic responsibilities might sometimes exactly entail violating that order.

Calling for a school strike is a politicising message in itself: pupils decide to distance themselves from the place that is attributed to them in society. This is the type of argument Rancière (2001; see also Dikeç, 2012) uses when conceptualising political action: By breaching the established 'police order,' which requires pupils to attend school every single school day, they politicise their own role or position in society. This does not mean that the extent to which pupils have to emancipate themselves from social expectations does not vary greatly. While some get parental approval and even support from their (head) teachers to join the demonstrations, others have a much harder path to walk. However, in both cases, they make themselves into political subjects, who no longer understand themselves merely as school pupils but also as potentially active agents of change. Furthermore, through their actions, they create a conflict in society, not only between politicians but also between (head) teachers, parents, and even pupils themselves. As Mouffe $(2002,2006)$ has convincingly argued, conflict can stir passion, as it shows that something is at stake. It can thereby set in motion processes of political subjectification. That the Climate Strikes are a passionate affair is clear from the intense atmosphere during the demonstrations. The improvised and uncontrolled parade through the city, the climbing on scaffolds and carrying of road signs, the sexualised messages-all contribute to the subversive character of the strikes.

While the politicising dynamic starts with the question of whether it is legitimate to skip school for the climate, the dynamic does not stop there. Maybe for the first time in Belgian history, we witness an explicit discussion in the centre of the political arena on what has to happen to tackle climate change. Because of the centrality of the topic and the passion with which it is publicly displayed, voices from all over the political spectrum feel obliged to position themselves. Significantly, however, Youth for Climate does not really take position itself.

\section{One Generation, One Voice}

One generation, one voice. We demand climate justice to ensure a promising future for our generation and the generations that follow. (Youth for Climate, 2019a)

During the demonstrations, the demand for intergenerational justice figures centrally. With slogans like "It is Our Future," "Our World, Our Future, Our Choice," and "Don't Burn Our Future," the youth climate strikers accuse previous generations of having left them with bleak future perspectives. By pointing to themselves as the future victims 
of climate change, they do not only establish a dividing line, but also point to and enact a subject of change.

However, not long after the first strike, their own complicity in the climate crisis is publicly displayed. Critics denounce the double standard within the climate strikers' discourse, targeting in particular the flying behaviour of many young people. "But if they go on holiday, the teenagers take the plane, which is, as we know, a big source of pollution," is stated in a press release on the day of the very first strike (Van Driessche, 2019). The youth climate strikers answer that structural changes are needed, not individual ones: "It should not only be about what citizens can do themselves. Much more is needed. We need structural action if we want to avoid the coming catastrophe" (Youth for Climate, 2019b). Furthermore, they denounce the depoliticising thrust of the critique. As a well-shared op-ed states: "As soon as young people act like citizens, one tries to turn them into consumers again. While ministers pretend to be happy with the juvenile climate engagement, they try to get rid of the political message" (Vandepitte et al., 2019). Still, the question remains whether young people are really only victims of climate change. Slogans such as "One Generation, One Voice" tend to make abstraction from the massive inequalities in responsibilities and victimhood, both in the here and now and in what is framed as 'our common future.' Sherilyn MacGregor (2014) speaks in this context about the 'big we' which has characterised environmental discourse for decades. Erik Swyngedouw (2015) argues that, in so far as climate change is projected into the future, abstraction is made from those who are living in the apocalypse here and now. With an intergenerational dividing line, both the previous and the future generations also risk being presented as homogenised categories.

Definitely, every politicisation entails a depoliticisation (Kenis, 2015; see also Mouffe, 2006). Every construction of an 'us' and 'them' conceals, or at least de-emphasises, other divisions, internal to the constructed 'us' and 'them.' It is never possible to politicise all potential conflict lines without dissolving a movement as a united entity. Politicising every potential conflict line means there is no 'us' anymore but only a sum of individuals who agonistically relate to each other. At the same time, an 'us' can exist only by mercy of a 'them.' In that sense, the challenge is to keep the 'us' big enough to have political leverage and be able to speak of a movement, but not so big that it includes everyone. In other words, politicisation is a double-edged sword. As a result, movements are always and by definition balancing unstably between different us-them formations and are characterised by a continuous negotiation on where to draw the lines between multiple potential 'us-s' and 'them-s'. The challenge this brings becomes clear soon. Where the movement starts with Youth for Climate, they are quickly joined by Students for Climate, Scientists for Climate, Workers for Climate, and even Grandparents for Climate. The movement broadens, and as a result its initial fault line evaporates. Whereas part of its mobilising thrust resided in the establishment of a conflict line, soon the movement ends up with an 'all together' discourse again.

\section{The Future is Haunted by the Past}

How can I study, pursue a career and have children when the world is about to fall apart? (Wauters, 2019)

This does not mean that an intergenerational conflict line cannot be interesting or politicising as such. Several social movements have aimed at realising social change by drawing a line between the current generation and the previous ones, emancipating themselves from the legacy of the past. A well-known example is the generation of May ' 68 and the way in which they aimed at breaking with existing forms of authority in the family or at school, or with consumer society. Staging yourself as 'the new generation' that will make the difference can definitely be a very politicising act: It is an attempt to start anew, to uproot the foundations of the existing social order and put society on a new footing. Is this acknowledgement of the fundamental alterability of the foundations of the hegemonic order not exactly what politicisation is about? As Slavoj Žižek (2000, p. 199) puts it: "The political act (intervention) proper is not simply something that works well within the framework of the existing relations, but something that changes the very framework that determines how things work."

However, while for May '68ers the future was open, for the youth climate strikers the future is haunted by the past. A famous wall painting of the period of May '68 reads: "The future will only contain what we put into it now." The same, however, cannot be said of the predicament the youth climate strikers find themselves in. Their frustration is exactly that they will not be able to get rid of the legacy of the past. The past looks at them from the future: the greenhouse gases emitted in the past are there to stay. Even worse, their cumulative effect will be felt only in the future. But there are other differences between the generation of May' 68 and the school skippers for climate as well, characterising the School Climate Strikes in ways which sometimes correspond to the depoliticising thrust that Swyngedouw $(2007,2010)$ criticises in mainstream climate discourse. To start with, the discourse of Youth for Climate does not so much start from the desire to create another future as from the need to do so. While May '68 was about changing 'life as we know it,' at least part of the youth climate movement wants to ward off climate change in order to preserve or protect what we currently value and know. While May '68 was hugely emancipatory in terms of young people's self-understanding, staging themselves as the generation that would make the difference, the School Climate Strikes ask people in power to act on their behalf. Finally, and most importantly, the intergenerational conflict of May '68 was accompanied by a strong politicisation of dividing lines in the here and now. 


\section{Empty Demands}

The actions of Youth for Climate are intended to bring politicians, CEOs and powerful people together to implement ecological measures. (Youth for Climate, 2019a)

Dividing lines in the here and now are exactly what Youth for Climate's public discourse seems to be lacking. As they argue: "It is important to reach out to everyone in order to tackle the climate problem together" (Youth for Climate, 2019a). It is at least a remarkable observation: While the world is polarising, the youth climate movement tries to keep or bring everyone together (again). The necessary condition for this far-reaching form of collaboration is that the movement keeps its demands empty. Its main objective is the establishment of a climate law, without much substantial content attached to it. Along the same lines, the movement argues that "the next government needs to be a climate government" (Youth for Climate, 2019a), regardless of the political parties which constitute it. They claim they do not need to answer the question of what has to happen exactly. As they contend: "This is not something Youth for Climate has to figure out. There are enough (climate) experts who are currently ignored" (Youth for Climate, 2019a).

In line with broader international tendencies, it is first and foremost the political right which denounces the apolitical thrust of this approach. In an inflammatory debate, a Flemish nationalist politician argues that betting on a climate law "opens the door to a system in which judges can determine what politics can decide" (Cattebeke, 2019). A centre-right liberal politician, in turn, complains that in this way, "climate politics comes into the hands of judges and technocrats," and a Christian-democrat politician argues that politics "has the task of voting for concrete proposals that are clear in terms of what they stand for" (Cattebeke, 2019). The movement, however, does not seem to be impressed by the reproach of being apolitical. To the contrary, the apolitical character of their approach is exactly what they consider a strength. They assert that they start from "an apolitical standpoint-because climate is a cause which concerns everyone" (Youth for Climate, 2019a). More specific guidelines have to come from "an independent panel of climate experts" and have to be based on "neutral scientific facts" (Youth for Climate, 2019a). To put these ideas into practice, they address Flemish Government Architect Leo Van Broeck and former President of the IPCC Jean-Pascal van Ypersele and "urge them to let [them] and policy makers know which evidence-based solutions exist to halt the climate crisis" (Youth for Climate, 2019b).

The claim that all their proposals are apolitical-or at least neutral, drawing directly on scientific researchis striking. De Moor et al. (2020) observe in this context a broader, international evolution in which "the main change [in comparison with previous grassroots climate mobilisations] appears to be the use of a more politically 'neutral' framing directed more strongly at state than non-state actors." Importantly, the movement's political allies, like Scientists for Climate, make similar claims. A petition which gathered more than 3500 signatures from academics in support of the Belgian School Strikes for Climate adopts a for scientists unusual 'political' standpoint of unconditionally embracing the actions of the school climate strikers, and a rather radical discourse on the measures which should be implemented to turn the tide. At the same time, however, they emphasise that their proposals are "neutral" and "merely based on scientific facts" (Scientists 4 Climate, 2019), failing to acknowledge the political character of their choices.

Surely, it is part of science's self-understanding to perceive itself as neutral and even the opposite of politics (Lievens \& Kenis, 2018). Still, that does not mean that, in the construction of scientific discourses, no political processes take place (Goeminne, 2012; Kenis, 2020). Not only are the epistemological boundaries of scientific research partly politically determined, but every translation into policy proposals also entails a decision in terms of which scientific findings to focus on. Because of the very nature of climate change, a very wide range of human activities can be scientifically shown to contribute to climate change. Exactly this lack of a clear object of change is one of the main reasons why climate change is so liable to depoliticisation (Kenis \& Lievens, 2014). The challenge is therefore not to prove that a certain activity has a climate impact, as almost every activity does, but to acknowledge that targeting particular activities always entails, next to a scientific evaluation, also a political choice.

Of course, there might be good reasons for keeping the demands empty and for opting for a strategic depoliticisation. It can help keep the movement together and prevent it from being absorbed by what was quickly developing into a very tense political playing field during the first weeks of the School Climate Strikes. But the main reason the movement opted for a depoliticised discourse seems to lie elsewhere. More precisely, it seems to be inspired by a 'political' choice. Just as the 'postpolitical condition' never meant that politicising voices were entirely absent (Mouffe, 2006), so does the current, more 'politicised' conjuncture not mean that depoliticising tendencies are no longer present. In that sense, the explicitly apolitical features of the movement's discourse could be considered the death throes of a vanishing post-political hegemony, or even an attempt to restore or revitalise a lost post-political condition which was omnipresent in green thinking for decades and which was seen as a necessary condition for tackling climate change.

\section{Depoliticisation, Recuperation, and Neutralisation}

Leaving the determination of the content of the climate struggle to actors outside the movement entails a risk. 
It means everyone can appropriate the struggle and give it their own content and direction. This has a positive side: it means that a real agonistic debate and thereby a process of politicisation around the topic can arise. However, it also means that under an apolitical umbrella, a political project can take shape.

\subsection{Sign for My Future}

On 5 February 2020, shortly after the first Belgian School Strikes for Climate, Sign for My Future is launched: an impressive, corporate-funded environmental advertisement campaign, including a large number of radio and TV commercials, which was set up by a partnership between the institutionalised environmental movement, hundreds of CEOs, media people, and academics. It is the largest of its kind ever launched in Belgium. The campaign presented itself as "a citizens' initiative that has developed into a broad coalition of young people, corporate executives, civil society organisations, the media and the academic world" (Sign for My Future, 2019, author's italics). While the coming together of both initiatives seems a coincidence, convergences develop promptly. Leading figures of the Youth Climate Strikes, such as Anuna De Wever and Kyra Gantois, are present at the opening event and publicly support the campaign. Furthermore, there is a striking similarity between their aims: a climate law, an independent advisory panel of climate experts, and a governmental investment plan. Similar to Youth for Climate's discourse, their proposals are directed towards the government and presented as merely apolitical.

Slavoj Žižek (1994) analyses these kinds of gestures as the 'masterstroke of ideology.' As he argues, the dominant ideology is the one that succeeds in presenting itself as the opposite of ideology: as neutral, merely scientific, or technological; as apolitical. Crucially, under the guise of an apolitical discourse, a political project inevitably takes shape. In the case of Sign for My Future, the underlying political stakes are already revealed in the choice for a particular messenger: a group of hundreds of CEOs (e.g., BNP Paribas, IKEA, Microsoft, Danone, Proximus, and Unilever) present themselves as allies in the struggle against climate change. Similarly, demands such as the establishment of a governmental investment plan "to help citizens and companies make the transition to a sustainable society" (Sign for My Future, 2019) reveal underlying political stakes. The point is that an apolitical discourse is merely a political discourse which presents itself as apolitical (Kenis, 2015). As Laclau and Mouffe (2001; see also Mouffe, 2006) contend: While all social relations are discursively constructed, and this always entails the exercise of power, discourses can remain blind to their own political dimension, or actively conceal it. This is what makes them depoliticised or post-political. A politicised and democratic discourse, in contrast, is one which fully recognises its political inscription. In other words, under the umbrella of an apolitical discourse, a political project takes shape. The difference is that it is not recognised as such and is therefore much less easily contestable.

\subsection{Struggling to (De)Politicise Climate Change}

Sign for My Future aims to put pressure on the government through a large-scale petition. With posters spreading messages such as "When I am older, I want to see tornadoes on television, not in my garden," "When I am older, I want to shop for shoes, not for flippers," "When I am older, I want to play football on a green field, not in a dry sand pit," they aim at collecting signatures from a broad public. At the same time, the campaign is increasingly contested on social media. Is the climate struggle about saving 'life as we know it'? Is it about warding off the climate disasters that threaten 'us'? Despite the impressive coalition, the Sign for My Future campaign is not the big success its designers had hoped for. The petition gathers 267,000 signatures, which is significant, but little in comparison with the resources which were put into it, as one of its initiators later publicly recognised (Dheedene, 2019). The campaign keeps relying on (social) media and is barely picked up by grassroots activists gathering signatures in the streets. Its 'consensus' narrative about preserving 'life as we know it,' spread through slogans concocted by marketing firms, not only misses the agonistic dimension which can trigger passion by showing that something is at stake (Mouffe, 2002), but also turns climate change into something superficial or meaningless. Who would be passionate about mobilising for such an empty stake? The hidden political message fuelled the suspicion.

The initiators of the campaign, however, seem struck dumb by the unexpected turn of events. Big is the consternation that an initiative with a goal as noble as tackling climate change is criticised. Three assumptions figure centrally in the ensuing debate. First, there is the assumption of 'convergence spaces': the idea that different environmental initiatives can neatly exist next to each other, as in the end, they all work towards the same goal (North, 2011; Routledge, 2003). As a well-shared oped, which aims at countering the critiques, reads: "A climate transition will happen when a hundred flowers can bloom" (Goris, 2019). The problem with such a representation is that it fails to acknowledge the struggles at play below the surface and that it denies that divergent ways of tackling climate change can be politically incompatible (Kenis, 2019). Second, there is the assumption that we need 'consensus' in order to arrive at change. This is exactly what generates the depoliticising dynamic Mouffe (2006) has criticised in her work on post-politics. The problem with 'consensus' discourses is that they misrecognise the constitutive and mobilising role of agonism in society and prevent the revelation of the political grounds behind the technocratic and market-oriented approaches at play. Third is the assumption that 'the people' are apolitical, and therefore the only way to address 
them would be through an apolitical approach. As the chief editor of $\mathrm{MO}^{*}$ magazine states:

I see the petition...as an instrument to communicate with very large groups of citizens who are situated in the misty centre of the debate....Those citizens...easily represent $50 \%$ of the electorate. This is not the moment to be right in your own bubble, but also within broader society (Goris, 2019)

Stated differently, the campaign is assumed to appeal to a supposedly apolitical public that would be situated somewhere in-between centre left and centre right. But are 'the people' so apolitical today?

While the world is polarising, the new climate movements project an aversion of politics on 'the people,' sticking to a post-political narrative whose time has already passed. The regional, federal, and European elections of Sunday 26 May 2019 are experienced as a slap in the movement's face. "Flanders is radicalising," reads a newspaper headline (Eeckhout, 2019). The predicted victory for the green party does not materialise. The centre parties lose to the benefit of the radical left and especially the far right.

\subsection{Depoliticising Climate Change in a Polarising World}

While the Youth Climate Strikes were highly successful in terms of mobilising large numbers of people and succeeded in putting climate change at the heart of the public agenda for months on end, it subsequently declined without leaving many tangible results. The emptiness of its demands made it relatively easy for oppositional forces to endorse the movement's demands while sticking to 'business as usual,' thereby "neutralis[ing] [the movement's] subversive potential," as Mouffe (2018, p. 34) warns. In the same line, it allowed mainstream voices to fill the void and, thereby, its demands to be "recuperated by the existing system" (Mouffe, 2018, p. 34). Consequently, the mobilising energy withered away. The last calls for a strike no longer attracted many participants, and after the elections of 26 May 2019, the movement was struck by internal crises. This does not mean the movement did not realise significant gains on the symbolic level: climate change has been staged as a matter of concern in unprecedented ways. Furthermore, for young people, the strikes might well have been the politicising experience of a lifetime. As Fisher (2019) notes: "This growing movement is important beyond its potential impact on climate policy because it is creating a cohort of citizens who will be active participants in democracy."

\section{Conclusion}

Following Mouffe (2018, p. 9), who cites Machiavelli in this respect, the task is to write "in the conjuncture" instead of merely reflecting "over the conjuncture." This requires taking position in the here and now. This positioning has to start from an estimation of the current political situation. Whereas a depoliticised climate discourse easily thrived in a post-political atmosphere, the political context is different today. In a polarising world, the challenge is "to seize the populist moment" by giving an emancipatory and democratic thrust to the politicising tendencies which are present in society (Mouffe, 2018, p. 1). One way of doing that is through a politicisation of our perception of historical time.

As I have argued in this article, projecting climate change into the future discursively conceals that the catastrophe is already here. Focusing on the here and now leads to a radically different position, allowing politicisation along an intersection of social justice lines. For that reason, it might be more interesting to understand our current predicament in terms of the Anthropocene. While the concept of the Anthropocene has been rightly criticised for being discursively homogenising and therefore depoliticising in itself (Malm \& Hornborg, 2014), and arguably it would be better to speak about the Capitalocene (Moore, 2016) or Oliganthropocene ("epoch of a few men and even fewer women"; Swyngedouw, 2013b), the reframing of the now as the moment of crisis, as the ruin on which another future has to be built, might be politically more interesting than fighting an enemy whose teeth have yet to be revealed. If we situate doomsday in the past, the future might become more promising again. If there is no reason to keep what we have, emancipatory politics become an option again. Furthermore, opening up the debate to more fundamental questions on how we as human beings, for the first time in history and self-consciously though mostly unwillingly, inscribe ourselves in geological processes can radicalise and even revolutionise the levels of change we allow in our imaginaries (Clark, 2010). Finally, such an approach makes it easier to connect with other struggles on the basis of which an emancipatory and intersectional frontier can be built.

Drawing on Laclau and Mouffe's (2001) earlier work, such a frontier could be built through constructing chains of equivalence between nodal points from a range of different struggles, such as climate, anti-racist, and antiausterity politics. Interestingly, we recently also witnessed the emergence of a number of initiatives along these lines. With slogans like "Burn Borders Not Coal" (Ende Gelände), "The Climate Crisis Is a Racist Crisis" (Black Lives Matter), and "Climate Refugees Welcome" (Lesbian and Gays Support the Migrants), activists have emphasised the intersectionality of struggles. In the same line, it might be useful to think about ways to 'internalise the enemy' and move beyond targeting $\mathrm{CO}_{2}$. By pointing to specific social practices here and now, the opponent acquires an identifiable face (Kenis \& Lievens, 2021). Also, at this level, interesting initiatives have been developed in recent years. Examples include the Dutch initiative \#Shellmustfall and its Belgian counterpart \#Ineoswillfall. Still, none of these initiatives have 
been as successful as the School Strikes for Climate so far, especially in terms of their mobilising capacity. The latter might partly testify to the unpredictability of forms of social upheaval: it is not because you follow all the steps that you will have a cake.

\section{Acknowledgments}

I want to thank the two anonymous reviewers as well as Ewoud Vandepitte (University of Antwerp) for their feedback on an earlier version of this article. I want to thank all climate activists, young and old, who engage in the emancipatory struggle against climate change. More in particular, I want to thank the school strikers for climate for their bravery and readiness to break with conventional institutions and look at what is really important in life. I also and especially want to thank everyone who was happy to talk to me in person and who shared their experiences, sorrows, and hopes for a better world.

\section{Conflict of Interests}

The author declares no conflict of interests.

\section{References}

Bond, S., Diprose, G., \& Thomas, A. C. (2019). Contesting deep sea oil: Politicisation-depoliticisationrepoliticisation. Environment and Planning C: Politics and Space, 37(3), 519-538.

Boudry, M. (2019, March 13). Anuna en Kyra, jullie onderschatten het menselijk vernuft [Anuna and Kyra, you underestimate human ingenuity]. Knack. Retrieved from https://www.knack.be/nieuws/belgie/anunaen-kyra-jullie-onderschatten-het-menselijkvernuft/article-opinion-1439595.html

Boykoff, M., \& Pearman, O. (2019). Now or never: How media coverage of the IPCC special report on $1.5^{\circ} \mathrm{C}$ shaped climate-action deadlines. One Earth, 1(3), 285-288.

Cattebeke, H. (2019, March 26). Groenen richten pijlen op Open VLD en CD\&V voor grondwetswijziging. Klimaatwet verhit de gemoederen in de Kamer [Greens target Open VLD and CD\&V for constitutional change. Climate law leads to heated debate in Parliament]. Het Nieuwsblad. Retrieved from https://www. nieuwsblad.be/cnt/dmf20190326_04282729

Clark, N. (2010). Volatile worlds, vulnerable bodies. Theory, Culture \& Society, 27(2/3), 31-53.

Dheedene, H. (2019, November 2). Is het momentum van de klimaatbeweging voorbij? [Did the momentum of the climate movement pass already?]. De Tijd. Retrieved from https://www.tijd.be/politiekeconomie/belgie/algemeen/is-het-momentum-vande-klimaatbeweging-voorbij/10177949.html

de Moor, J., de Vydt, M., Uba, K., \& Wahlström, M. (2020). New kids on the block: Taking stock of the recent cycle of climate activism. Social Movement
Studies. Advance online publication. https://doi.org/ 10.1080/14742837.2020.1836617

De Wolf, L., \& Arnoudt, R. (2019, January 10). Organisator klimaatprotest Anuna De Wever (17): "Ik wil politici horen zeggen dat ze iets gaan doen aan het probleem" [Organiser climate protest Anuna De Wever (17): "I want to hear politicians saying that they will do something about the problem"]. Vrt NWS. Retrieved from https://www.vrt.be/vrtnws/nl/2019/ 01/10/organisator-klimaatprotest-anuna-de-weverik-wil-politici-hore/?fbclid=IwAR1WdugXT83ikt8BiT MzXLWBo0OAn8icqEb3Q615xCpPvlHQbu78uol00sQ

Dikeç, M. (2012). Space as a mode of political thinking. Geoforum, 43(4), 669-676.

Eeckhout, B. (2019, May 26). Vlaanderen radicaliseert: Vlaams Belang wint de verkiezingen, PVDA haalt de kiesdrempel [Flanders is radicalising: Vlaams Belang wins the elections; PVDA reaches the electoral threshold]. De Morgen. Retrieved from https://www. demorgen.be/nieuws/vlaanderen-radicaliseertvlaams-belang-wint-de-verkiezingen-pvda-haalt-dekiesdrempel bed38141

Fisher, D. R. (2019). The broader importance of \#FridaysForFuture. Nature Climate Change, 9(6), 430-431.

Goeminne, G. (2010). Climate policy is dead, long live climate politics! Ethics, Place and Environment, 13(2), 207-214.

Goeminne, G. (2012). Lost in translation: Climate denial and the return of the political. Global Environmental Politics, 12(2), 1-8.

Goris, G. (2019, February 6). Klimaatomwenteling komt er als honderd bloemen kunnen bloeien [A climate transition will happen when a hundred flowers can bloom]. MO* Mondiaal nieuws. Retrieved from https://www.mo.be/commentaar/ klimaatomwenteling-komt-er-als-honderdbloemen-kunnen-bloeien

Howarth, D. (2000). Discourse. Buckingham: Open University Press.

Howarth, D., Norval, A. J., \& Stavrakakis, Y. (2000). Discourse theory and political analysis. Identities, hegemonies and social change. Manchester: Manchester University Press.

Kenis, A. (2015). From individual to collective change and beyond. Ecological citizenship and politicisation (Unpublished Doctoral dissertation). University of Leuven, Leuven, Belgium.

Kenis, A. (2019). Post-politics contested: Why multiple voices on climate change do not equal politicisation. Environment and Planning C: Politics and Space, 37(5), 831-848.

Kenis, A. (2020). Science, citizens and air pollution: Constructing environmental (in)justice. In T. Davies \& A. Mah (Eds.), Toxic truths: Environmental justice and citizen science in a post-truth age (pp. 282-300). Manchester: Manchester University Press.

Kenis, A., \& Lievens, M. (2014). Searching for 'the politi- 
cal' in environmental politics. Environmental Politics, 23(4), 531-548.

Kenis, A., \& Lievens, M. (2015). The limits of the green economy. From re-inventing capitalism to repoliticising the present. London: Routledge.

Kenis, A., \& Lievens, M. (2021). Politicizing air: On the political effects of spatial imagination. In F. Landau, L. Pohl, \& N. Roskam (Eds.), (Un)groundingPost-foundational geographies (pp. 261-278). London: Transcript.

Kenis, A., \& Mathijs, E. (2014). Climate change and postpolitics: Repoliticising the present by imagining the future? Geoforum, 52, 148-156.

Laclau, E., \& Mouffe, C. (2001). Hegemony and socialist strategy: towards a radical democratic politics. London: Verso.

Lievens, M., \& Kenis, A. (2018). Social constructivism and beyond. On the double bind between politics and science. Ethics, Policy \& Environment, 21(1), 81-95.

MacGregor, S. (2014). Only resist: Feminist ecological citizenship and the post-politics of climate change. Hypatia, 29(3), 617-633.

Machin, A. (2013). Negotiating climate change. Radical democracy and the illusion of consensus. London: Zed Books.

Maeseele, P. (2015). Beyond the post-political Zeitgeist. In A. Hansen \& R. Cox (Eds.), A handbook of environment and communication (pp. 429-443). New York, NY: Routledge.

Malm, A., \& Hornborg, A. (2014). The geology of mankind? A critique of the Anthropocene narrative. The Anthropocene Review, 1(1), 62-69.

Marchart, O. (2007). Post-foundational political thought: Political difference in Nancy, Lefort, Badiou and Laclau. Edinburgh: Edinburgh University Press.

Martiskainen, M., Axon, S., Sovacool, B. K., Sareen, S., Furszyfer Del Rio, D., \& Axon, K. (2020). Contextualizing climate justice activism: Knowledge, emotions, motivations, and actions among climate strikers in six cities. Global Environmental Change, 65, 102-180.

McCarthy, J. (2013). We have never been "postpolitical." Capitalism Nature Socialism, 24(1), 19-25.

Moore, J. (Ed.). (2016). Anthropocene or capitalocene? Nature, history, and the crisis of capitalism. Kairos: PM Press.

Mouffe, C. (2002). Politics and passions. The stakes of democracy. London: CSD Perspectives.

Mouffe, C. (2006). On the political. London: Routledge.

Mouffe, C. (2018). For a left populism. London: Verso.

North, P. (2011). The politics of climate activism in the UK: A social movement analysis. Environment and Planning D, 43(7), 1581-1598.

Rancière, J. (1998). Disagreement: Politics and philosophy. Minneapolis, MN: University of Minnesota Press.

Rancière, J. (2001). Ten theses on politics. Theory \& Event, 5(3). https://doi.org/10.1353/tae.2001.0028

Routledge, P. (2003). Convergence space: Process geographies of grassroots globalization networks. Transactions of the Institute of British Geographers, 28, 333-349.

Scientists 4 Climate. (2019). Strengthen your climate ambitions! Scientists 4 Climate. Retrieved from https://www.scientists4climate.be/wp-content/ uploads/2020/02/Strengthen-your-climateambitions.pdf

Sign for My Future. (2019). Deze Belgen doen al mee. Jij ook? Wat vragen we? [These Belgians are already participating. Will you too? What are we demanding?]. Sign for My Future. Retrieved from https:// signformyfuture.be/nl

Swyngedouw, E. (2007). Impossible "sustainability" and the postpolitical condition. In R. Krueger \& D. Gibbs (Eds.), The sustainable development paradox: Urban political economy in the United States and Europe (pp. 13-40). London: The Guilford Press.

Swyngedouw, E. (2010). Apocalypse forever? Theory, Culture \& Society, 27(2/3), 213-232.

Swyngedouw, E. (2013a). The non-political politics of climate change. ACME: An International E-Journal of Critical Geographies, 12(1), 1-8.

Swyngedouw, E. (2013b). Trouble with nature: "Ecology as the new opium for the masses". Second meeting of the human-nature platform. Paper presented at the Second Meeting of the Human-Nature Platform, Lausanne, Switzerland.

Swyngedouw, E. (2015). Foreword: Apocalypse now? From the marketisation to the politicisation of the environment. In A. Kenis \& M. Lievens (Eds.), The limits of the green economy (pp. 261-278). London: Routledge.

Urry, J. (2011). Climate change and society. Cambridge: Polity Press.

Vandepitte, E., Kuyper, T., Herweyers, L., Boost, D., Van Dam, S., Meyermans, A., . . Saeys, A. (2019, January $30)$. Het over de individuele inspanningen van klimaatbetogers hebben is vandaag een schijngevecht [Talking about the individual efforts of climate demonstrators is shadow-boxing]. Knack. Retrieved from https://www.knack.be/nieuws/planet-earth/ het-over-de-individuele-inspanningen-vanklimaatbetogers-hebben-is-vandaag-eenschijngevecht/article-opinion-1423757.html

Van Driessche, C. (2019, January 10). "Dat we spijbelen is ons probleem, klimaatprobleem is veel groter": Wie zijn de 2 tieners die oproepen tot actie? ["That we skip school is our problem, but the climate problem is much bigger": Who are the two teenagers who call for action?]. Vrt NWS. Retrieved from https:// www.vrt.be/vrtnws/nl/2019/01/08/twee-meisjesroepen-op-voor-meer-aandacht-voor-het-klimaat

Verbeke, H., \& Vanderstricht, Z. (2019, February 2). Waarom wij een dag spijbelen? Onze toekomst hangt niet enkel af van onze studie, maar ook van het klimaat [Why do we skip school for the climate? Our future does not depend on our studies only, but also 
on the climate]. Knack. Retrieved from https://www. knack.be/nieuws/belgie/waarom-wij-een-dagspijbelen-onze-toekomst-hangt-niet-enkel-af-vanonze-studie-maar-ook-van-het-klimaat/articleopinion-1424289.html

Wauters, A. (2019, January 7). Jongeren roepen op om te spijbelen voor het klimaat: "Hoe kan ik nog studeren als de wereld straks om zeep is?" [Young people are calling to skip school for the climate: "How can I study when the world is about to end?"]. De Morgen. Retrieved from https://www.demorgen. be/nieuws/jongeren-roepen-op-om-te-spijbelenvoor-het-klimaat-hoe-kan-ik-nog-studeren-als-dewereld-straks-om-zeep-is $\sim$ b1170046

Youth for Climate. (2018, December 29). Join the movement \#youthforclimate [Facebook status update]. Retrieved from https://www.facebook.com/239512 9133835855/videos/373156863443853

Youth for Climate. (2019a). About us. Youth for Climate. Retrieved from https://youthforclimate.be

Youth for Climate. (2019b). Brief Youth for Climate [Letter Youth for Climate]. Youth for Climate. Retrieved from https://www.klimaatpanel.be/nl

Zo'n 3.000 klimaatspijbelaars brengen krachtige boodschap in Brussel: "Er is geen planeet B" [Around 3,000 climate strikers deliver powerful message in Brussels: "There is no planet B"]. (2019, January 10). HLN. Retrieved from https://www.hln.be/binnenland/zon3-000-klimaatspijbelaars-brengen-krachtigeboodschap-in-brussel-er-is-geen-planeetb a9d4482a

Žižek, S. (1994). Mapping ideology. London: Verso.

Žižek, S. (2000). The ticklish subject: The absent centre of political ontology. London: Verso.

\section{About the Author}

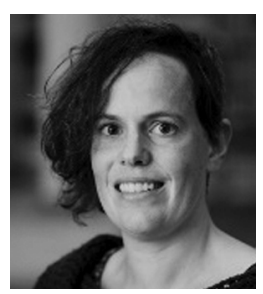

Anneleen Kenis (PhD) is a Senior Research Fellow of the Research Foundation Flanders (FWO). She has contributed to the scholarly and activist debate on processes of politicisation and depoliticisation in both hegemonic (e.g., the Green Economy, Transition Management) and counter-hegemonic environmental discourses (e.g., Climate Justice Action, Transition Towns, Field Liberation movement, urban air pollution struggles). She currently works on the role of emergency discourses, clashing temporalities, intergenerational conflicts and imaginaries of historical time in (de)politicising climate change. 